\title{
URGENSI HUKUM ADAT DALAM PEMBAHARUAN HUKUM PIDANA NASIONAL
}

\section{Urgency of Customary Law in the Renewable of National Criminal Law}

\author{
Rahmat Hi. Abdulah \\ Fakultas Hukum, Universitas Gadjah Mada \\ email: abdullahrahmat05@gmail.com
}

\begin{abstract}
Recognition of the existence of legal values and sense of justice that life is constitutionally recognized as the author explained earlier. One of the key concepts that evolved form of legal recognition or live in the community is the adoption of the system of sanctions in customary law (customary criminal) in the national legal system. Recognition and protection of sanction customary law becomes an important thing in the life of indigenous peoples, for the customary sanctions, then it can be constructed or create a balance and social harmony, interests between the human race and the individual, between the alliance (group) and wider society that is the basis from the minds of traditional Indonesian nation. Recognition of the importance of values in society as customary law (customary criminal) in the renewal of the national criminal law as the national law reform agenda is a necessity and demand to the fulfillment of social justice in accordance ideals of the Indonesian nation.
\end{abstract}

Keywords: Customary, Existence, Criminal Law Reform

\section{abstrak}

Pengakuan terhadap eksistensi nilai-nilai hukum dan rasa keadilan yang hidup itu diakui secara konstitusional sebagaimana telah penulis jelaskan sebelumnya. Salah satu konsep pokok bentuk pengakuan hukum yang berkembang atau hidup di masyarakat adalah dengan diadopsinya sistem sanksi dalam hukum adat (pidana adat) dalam sistem hukum nasional. Pengakuan dan perlindungan atas penerapan sanksi hukum adat menjadi suatu yang penting dalam kehidupan masyarakat adat, sebab dengan sanksi adat, maka dapat terkonstruksi atau tercipta keseimbangan dan harmonisasi sosial, kepentingan antara golongan manusia dan perorangan, antara persekutuan (kelompok) dan masyarakat luas yang merupakan dasar dari alam pikiran tradisional bangsa Indonesia. Pentingnya pengakuan terhadap nilai-nilai yang hidup di masyarakat sebagai hukum adat (pidana adat) dalam pembaharuan hukum pidana nasional sebagaimana agenda reformasi hukum 
secara nasional merupakan kebutuhan dan tuntutan untuk pemenuhan keadilan sosial sesuai cita-cita nasional bangsa Indonesia.

Kata kunci: Adat, Eksistensi, Pembaharuan Hukum Pidana

\section{A. Pendahuluan}

Pembangunan Nasional hingga saat ini telah memperlihatkan kemajuan, tidak hanya menyangkut pembangunan di bidang ekonomi semata namun menyangkut seluruh aspek kehidupan masyarakat termasuk pembangunan di bidang hukum. Kemajuan di bidang hukum ditandai dengan usaha untuk memperbaharui hukum itu sendiri, karena hukum sebagai salah satu penunjang utama dalam menjamin ketertiban masyarakat, diharapkan mampu mengantisipasi dan mengatasi segala tantangan, kebutuhan serta kendala yang menyangkut sarana dan prasarana, di samping itu juga harus lebih beradaptasi dengan perubahan-perubahan yang terjadi dalam masyarakat. Meskipun seringkali secara faktual, hukum berjalan lebih lamban daripada perkembangan dan perubahan berbagai hal di masyarakat. Termasuk dalam hal ini adalah hukum pidana sebagai bagian dari hukum.

Perubahan dan pembaharuan di bidang hukum pidana khususnya mengenai hukum pidana materiil (substantif) merupakan hal yang penting dan mendasar, karena hukum yang sekarang berlaku khususnya hukum pidana material peninggalan kolonial sudah tidak lagi dapat memenuhi kebutuhan hukum masyarakat Indonesia. Hal ini sesuai dengan realita hukum bahwa hukum pidana atau KUHP yang sekarang berlaku bukan berasal, berakar atau bersumber dari pandangan/konsep nilai-nilai dasar dan kenyataan sosio-politik, sosio-ekonomi dan sosio-budaya yang hidup dalam masyarakat Indonesia sendiri. Pembaharuan hukum pidana nasional merupakan salah satu masalah besar yag dihadapi bangsa Indonesia, khususnya dalam rangka mengubah dan mengganti KUHP (WvS) warisan kolonial Belanda yang sekarang berlaku karena dianggap tidak sesuai lagi dengan tuntutan dan nilai-nilai yang berkembang di masyarakat, menjadi KUHP Baru yang bersifat nasional sesuai dengan pandangan hidup bangsa yang berakar pada nilai-nilai sosial, budaya dan struktur masyarakat Indonesia.

Berkaitan dengan hal tersebut, maka pembaharuan hukum pidana di Indonesia khususnya hukum pidana material, sudah dilakukan sejak tahun 1946 dengan dikeluarkannya Undang-Undang Nomor 1 Tahun 1946. Pasal 5 Undang-undang tersebut menentukan bahwa "peraturan hukum pidana, yang seluruhnya atau sebagian sekarang tidak dapat dijalankan atau bertentangan dengan kedudukan Republik Indonesia sebagai negara merdeka atau tidak memunyai arti lagi, harus dianggap seluruhnya atau sebagian sementara tidak berlaku lagi". Sedangkan dalam pasal 8 merupakan perubahan kata- 
kata dan penghapusan berbagai pasal dalam KUHP. Namun perubahan yang demikian masih bersifat tambal sulam atau parsial, sehingga perlu dilakukan upaya pembaharuan secara menyeluruh atau pembaharuan secara total.

Sehubungan dengan hal tersebut, Barda Nawawi Arief menyatakan bahwa usaha melakukan pembaharuan hukum (pidana) pada dasarnya merupakan kegiatan yang berlanjut dan terus menerus (kontinu) tak kenal henti. Jerome Hall menyebutkan dengan istilah "a permanent on going enterprise". Khususnya di bidang pembaharuan hukum pidana, Jerome Hall menyatakan "improvement of the criminal law should be a permanent on going enterprise and detailed records should be kept". Dengan demikian menurut Jerome Hall "perbaikan/pembaharuan atau pengembangan hukum pidana harus merupakan suatu usaha permanen yang terus menerus dan berbagai catatan/dokumen rinci mengenai hal itu seharusnya disimpan dan dipelihara". ${ }^{1}$

Dalam rangka melakukan pembaharuan hukum pidana di Indonesia, tentu tidak terlepas dari tugas politik hukum untuk meneliti perubahanperubahan yang perlu diadakan terhadap hukum yang ada sehingga dapat memenuhi tuntutan-tuntutan dan kebutuhan-kebutuhan baru dalam masyarakat. Politik hukum berusaha meneruskan arah perkembangan tertib hukum, dari Ius Constitutum yang bertumpu pada kerangka landasan hukum yang terdahulu menuju pada penyusunan hukum di masa datang atau Ius Constituendum.

Barda Nawawi Arief secara jelas merumuskan latar belakang dan urgensi pembaharuan hukum pidana dapat ditinjau dari aspek sosio-politik, sosio-filosofis, sosio-kultural. Dengan demikian, pembaharuan hukum pidana pada hakikatnya mengandung makna, suatu upaya untuk melakukan reorientasi dan reformulasi hukum pidana yang sesuai dengan nilai-nilai sentral sosio-politik, sosio-filosofis, dan sosio-kultural masyarakat Indonesia yang melandasi kebijakan sosial, kebijakan kriminal, dan kebijakan penegakan hukum di Indonesia. Secara singkat dapatlah dikatakan, bahwa pembaharuan hukum pidana pada hakikatnya harus ditempuh dengan pendekatan yang berorientasi pada kebijakan (policy oriented approach) dan sekaligus pendekatan yang berorentasi pada nilai (value oriented approach). ${ }^{2}$

Menurut Prof. Sudarto, paling sedikit ada tiga alasan untuk mengadakan pembaharuan Kitab Undang-Undang Hukum Pidana tersebut, yaitu politis, sosiologis, dan praktis. ${ }^{3}$ Dipandang dari segi politis, Negara

\footnotetext{
${ }^{1}$ Barda Nawawi Arief, Beberapa Aspek Kebijakan dan Pengembangan Hukum Pidana (Edisi Revisi), (Bandung: Citra Aditya Bakti, 2005), hlm. 135.

${ }^{2}$ Barda Nawawi Arief, Bunga Rampai Kebijakan Hukum Pidana (Perkembangan Penyusunan Konsep KUHP Baru), (Bandung: Citra Aditya Bakti, 2010), hlm. 29.

${ }^{3}$ Aruan Sakidjo, Bambang Poernomo, Hukum Pidana: Dasar Aturan Umum Hukum Pidana Kodifikasi, (Jakarta: Ghalia Indonesia, 1990), hlm. 20.
} 
Republik Indonesia yang telah lama merdeka, sudah sewajarnya memunyai Kitab Undang-Undang Hukum Pidana yang diciptakan sendiri. Konsep KUHP yang diciptakan sendiri itu dapat dipandang sebagai lambang hukum nasional dan merupakan suatu kebanggaan dari negara yang telah merdeka dan melepaskan diri dari pengaruh hukum pada masa lalu. ${ }^{4}$

Dipandang dari segi sosiologis, yang lebih tepat dari segi antropologis, sebagaimana telah dikemukakan oleh para sarjana hukum adat seperti Van Vollenhoven, Ter Har, Idema, yang pada garis besarnya dapat disimpulkan bahwa Wetboek van Strafrecht atau KUHP yang berasal dari Netherland ini sudah tidak cocok lagi bagi bangsa Indonesia. Dalam KUHP tersebut belum mencakup perbuatan-perbuatan yang menurut ukuran bangsa Indonesia harus diancam dengan pidana, ternyata tidak dipidana dalam KUHP, misalnya masalah sumbang atau incest. ${ }^{5}$

Dipandang dari segi praktik sehari-hari mengapa KUHP sekarang itu harus segera diganti, karena tidak banyak orang yang menyadari bahwa sampai saat sekarang ini teks resminya dari KUHP yang berlaku di Indonesia ini masih bertuliskan dalam bahasa Belanda. Apabila petugas penerap hukum hendak menerapkan ketentuan-ketentuan yang terdapat didalamnya secara tepat seharusnya petugas tersebut mengerti bahasa belanda. Praktik hukum ini sulit diharapkan dari bangsa Indonesia yang pada masa sekarang sudah banyak yang kurang mengerti bahasa Belanda, oleh karena itu KUHP yang masih berlaku ini harus segera diganti kodifikasi Indonesia yang bersifat nasional. ${ }^{6}$

Dengan menggunakan metode perbandingan hukum, hukum pidana Indonesia sebagaimana terkandung dalam KUHP/WvS yang saat ini berlaku yang termasuk ke dalam keluarga civil law system atau Romano-Germanic familiy bukan satu-satunya konsep hukum untuk memecahkan masalah hukum. Sebenarnya masih ada konsep atau sistem hukum lain yang sepatutnya dikaji untuk lebih memantapkan upaya pembaharuan hukum pidana di Indonesia.

Pada Kongres PBB V tahun 1975 yang mengambil topik Prevention of Crime and the Treatment of Offenders, dihimbau pentingnya perubahan terhadap sistem hukum pidana yang sudah ketinggal zaman dan tidak sesuai dengan kenyataan dan tidak berakar pada nilai-nilai budaya masyarakat. Himbauan ini lebih ditujukan pada usaha untuk melakukan pemikiran ulang terhadap keseluruhan kebijakan kriminal (to rethink the whole of criminal policy). ${ }^{7}$

\footnotetext{
${ }^{4}$ Ibid.

${ }^{5}$ Ibid., hlm. 21.

${ }^{6}$ Ibid., hlm. 21-22.

${ }^{7}$ Barda Nawawi Arief, Bunga Rampai Kebijakan Hukum Pidana, (Bandung: Citra Aditya Bakti, 1996), hlm. 117.
} 
Memahami asumsi tersebut, jelaslah bahwa usaha untuk mengaji dan menggali hukum adat dan nilai-nilai yang hidup di masyarakat yang tersebar di nusantara terasa begitu penting. Pemikiran ini juga mendapat dukungan, seperti dari Roeslan Saleh yang mengatakan bahwa "... hal keberlakuan hukum adat khususnya, perlu mendapat perhatian. Ada hal yang memang dapat disusun dan akhirnya disistematik sedemikian rupa, sehingga berlaku sebagai bagian dari hukum pidana keseluruhan, yaitu yang dapat dimasukkan ke dalam hal-hal yang dapat meniadakan kesalahan tersangka/terdakwa, ataupun hal-hal yang akhirnya membenarkan perbuatan tersangka/terdakwa, hal-hal yang dalam ajaran hukum pidana termasuk dalam ajaran melawan hukum materiil dan ajaran kesalahan". 8

Sebagai identitas bangsa, eksistensi hukum adat mesti memiliki ciri dan karakteristik yang sesuai dengan filosofi dan budaya bangsa. Sudarto menegasan bahwa, "tidak salah kiranya, kalau sampai batas tertentu dapat dikatakan bahwa hukum pidana suatu bangsa dapat merupakan indikasi dari peradaban bangsa itu". ${ }^{9}$ Hukum pidana yang berlaku secara Nasional sekarang menentukan bahwa dalam hal menetapkan adanya tindak pidana dilarang menggunakan analogi. Ketentuan tersebut mempertegas prinsip legalitas yang menjadi prinsip utama dalam hukum pidana Nasional yang secara positif berlaku sekarang.

Realitasnya, kebiasaan masyarakat Indonesia memunyai kaidah tersendiri yang diantaranya memunyai sanksi yang biasa dikenal dengan hukum adat. Hukum adat yang demikian tentu tidak tertulis, dalam arti tidak menjadi hukum tertulis yang resmi disahkan negara sebagaimana halnya undang-undang. Hal tersebut mengindikasikan bahwa masyarakat Indonesia masih memegang teguh hukum tidak tertulis yaitu hukum adat itu sendiri beserta sanksi atas pelanggaran hukum tidak tertulis tersebut. Dengan demikian, kedudukan hukum adat berserta sanksi adatnya masihlah utuh dan teguh dipertahankan masyarakat Indonesia yang seharusnya menjadi perhatian dalam hal politik hukum pidana khususnya pembaharuan hukum pidana nasional, baik hukum pidana materiil maupun hukum pidana formil.

Bertolak dari penjelasan di atas, maka menjadi jelaslah bahwa hukum adat di Indonesia memunyai dasar berlakunya dan karenanya memiliki norma dan sanksi yang patut bagi masyarakat. Hukum adat tergolong ke dalam hukum tidak tertulis yang meliputi kebiasaan-kebiasaan yang timbul dan diikuti serta ditaati secara terus menerus, bahkan dapat melalui peralihan generasi yang berlangsung secara turun temurun oleh masyarakat adat di mana hukum adat itu tumbuh dan berkembang.

\footnotetext{
${ }^{8}$ Reimon Supusesa, Eksistensi Hukum Delik Adat Dalam Perspektif Pambaharuan Hukum Pidana di Maluku Tengah, Mimbar Hukum, Volume 24, Nomor 1, Februari 2012, hlm. 42

${ }^{9}$ Ibid., hlm. 44.
} 
Oleh karena itu, dengan latar belakang di atas maka penulis akan mencoba membahas tentang urgensi hukum adat dalam pembaharuan hukum pidana nasional.

\section{B. Pembahasan}

Setelah perang dunia kedua, banyak bermunculan Negara-Negara baru. Negara-negara ini mempelopori upaya untuk memperbaharui hukum pidana atau KUHP-nya. Di Indonesia sendiri, masih menggunakan KUHP peninggalan Belanda. Sudah beberapa kali KUHP warisan Belanda ini diajukan ke DPR untuk dibahas dan diperbaharui, namun hingga sekarang belum juga kunjung usai. Upaya pembaharuan ini dipandang perlu mengingat Indonesia sudah merdeka dan terdapat urgensi untuk menyusun suatu KUHP Nasional yang baru sebagaiman telah penulis sampaikan pada pendahuluan sebelumnya.

Menyusun suatu Kitab Undang-Undang Hukum Pidana yang baru dan bersumber dari jati diri bangsa sendiri tidaklah mudah. Ada banyak permasalah yang muncul di dalam penyusunan KUHP Nasional ini. Menurut guru besar hukum pidana, Soedarto ada 4 permasalah yang muncul di dalam upaya pembaharuan hukum pidana ini. Keempat masalah itu adalah: ${ }^{10}$

1. kriminalisasi dan dekriminalisasi;

2. masalah pemberian pidana;

3. pelaksanaan hukum pidana; dan

4. sejauh mana urgensi dibentuknya KUHP Nasional.

Pertama, kriminalisasi dan dekriminalisasi. Kedua istilah tersebut merupakan istilah yang agak baru dalam ilmu hukum. Dengan kriminalisasi dimaksudkan proses penetapan suatu perbuatan orang sebagai perbuatan yang dapat dipidana. Proses ini diakhiri dengan terbentuknya undang-undang di mana perbuatan itu diancam dengan suatu sanksi yang berupa pidana. Terbentuklah peraturan hukum pidana yang siap untuk diterapkan oleh hakim dan selanjutnya apabila dijatuhkan pidana, dilaksanakan oleh kekuasaan administrasi (eksekutif). Sebaliknya pengertian dekriminalisasi mengandung arti suatu proses di mana dihilangkan sama sekali sifat dapat dipidananya sesuatu perbuatan. Dekriminalisasi ini harus dibedakan dengan depenalisasi, di mana perbuatan yang semula diancam pidana, ancaman pidana ini dihilangkan akan tetapi masih dimungkinkan adanya penuntutan dengan cara lain ialah dengan melalui hukum perdata atau hukum administrasi. $^{11}$

Masalah kriminalisasi ini erat kaitannya dengan criminal policy. Criminal policy adalah usaha yang rasional baik dari masyarakat/pemerintah

\footnotetext{
${ }^{10}$ Sudarto, Hukum dan Hukum Pidana, (Bandung: Alumni, 1986), hlm. 31.

${ }^{11}$ Ibid.
} 
untuk menanggulangi tindak pidana baik menggunakan sarana penal maupun non-penal. Menurut Soedarto, ${ }^{12}$ ada 4 syarat yang harus diperhatikan dalam melakukan kriminalisasi: 1) Tujuan. Tujuan kriminalisasi adalah menciptakan ketertiban masyarakat dalam rangka menciptakan negara kesejahteraan (welfare state), 2) Perbuatan yang dikriminalisasi harus perbuatan yang menimbulkan kerusakan meluas dan menimbulkan korban, 3) harus mempertimbangkan faktor biaya dan hasil, berarti biaya yang dikeluarkan dan hasil yang diperoleh harus seimbang, 4) harus memperhatikan kemampuan apara penegak hukum. Jangan sampai aparat penegak hukum melampaui bebannya atau melampaui batas.

Kedua, pemberian pidana. Banyak yang mengatakan/mengira bahwa masalah pemberian pidana ini semata-mata masalah hakim. Hal ini dapat dipahami ketika Pasal 10 KUHP dijatuhkan. Padahal arti penting penentuan kualifikasi delik adalah menentukan pemidanaan yang akan dijatuhkan. Sudarto berpandangan bahwa masalah pemberian ini memunyai dua arti: ${ }^{13}$

1. dalam arti umum ialah menyangkut pembentuk undang-undang, ialah menetapkan stelsel sanksi pidana (pemberian pidana in abstracto); dan

2. dalam arti konkrit, ialah menyangkut berbagai badan atau jawatan yang kesemuanya mendukung dan melaksanakan stelsel sanksi hukum pidana itu.

Ketiga, pelaksanaan pidana. Undang-undang pidana tidak dapat beroperasi dengan sendirinya. Hukum hanya dapat beroperasi melalui orang. Untuk ini dibutuhkan peraturan-peraturan yang memungkinkan undangundang pidana itu dilaksanakan. Pedoman pelaksanaan pidana ini adalah Hukum Acara Pidana (KUHAP). Sebelumnya adalah HIR dan undangundang lain (UU Kepolisian, UU Kejaksaan, dan UU Mahkamah Agung). KUHAP hendak menyatukan penyidikan (penyidik berada di satu tangan) berdasarkan Pasal 284 ayat (2) KUHAP. Di Indonesia saat ini pelaksanaan hukum pidana masih fragmentasi dan instansi centris. Hal ini yang harus dirubah jika ingin melaksanakan hukum pidana secara tepat sasaran dan berdaya guna.

Keempat, sejauh mana urgensi dibentuknya KUHP Nasional. Kalau kita sekarang sudah memunyai Konsep Rencana KUHP, kita boleh merasa bersyukur. Namun melihat praktek bekerjanya sistem hukum pidana kita sekarang ini dapat diajukan pertanyaan sampai dimanakah urgensi bagi kita untuk memunyai KUHP baru? Untuk memberi jawaban secara pasti sebenarnya harus diadakan penelitian bagaimana sesungguhnya. Akan tetapi WvS yang berlaku sekarang dan dalam bentuknya yang sekarang ini tidak dapat dipertahankan terus menerus tidaklah perlu dipersoalkan. Hanya saja

\footnotetext{
${ }^{12} \mathrm{Ibid}$, hlm. 36.

${ }^{13}$ Ibid, hlm. 42
} 
alasannya terpaksa harus dicari secara spekulatif. Sedikitnya ada tiga alasan oleh Sudarto yang telah penulis sampaikan sebelumnya dalam pendahuluan tulisan ini tentang mengapa harus diadakan pembaharuan hukum pidana nasional. Selain ketiga pertimbangan tersebut, Muladi menambahkan satu pertimbangan lagi, yaitu pertimbangan adaptatif atau sebisa mungkin mengadaptasikan perkembangan yang terjadi di dunia Internasional tanpa harus menghilangkan nilai-nilai nasional.

Indonesia merupakan negara kepulauan yang memunyai beraneka ragam suku-suku bangsa, dan sudah tentu budaya serta norma-norma yang dianutnya akan berbeda-beda. Keanekaragaman ini akan melahirkan tata nilai yang berlain-lainan dari berbagai suku-suku masyarakat dalam memandang dan menyelesaikan berbagai persoalan yang terjadi di kalangannya, tidak terkecuali pada kasus-kasus yang berkaitan dengan kehormatan dan kesusilaan, karena hal ini tidak saja para pihak yang terlibat dalam kasus tersebut, melainkan juga melibatkan komunitas masyarakat yang lebih luas.

Di dalam Pasal 18 B ayat (2) Undang Undang Dasar Negara Republik Indonesia 1945, dinyatakan dengan tegas bahwa "Negara mengakui dan menghormati ketentuan-ketentuan masyarakat hukum adat beserta hak-hak tradisionalnya sepanjang masih hidup dan sesuai dengan perkembangan masyarakat dan prinsip Negara Kesatuan Republik Indonesia yang diatur dalam undang-undang". Demikian pula Pasal 28 I ayat (3) dinyatakan bahwa, identitas budaya dan hak masyarakat tradisional dihormati selaras dengan perkembangan zaman dan peradaban.

Di dalam lampiran Undang-Undang Nomor 17 Tahun 2007 tentang Rencana Pembangunan Jangka Panjang Tahun 2005-2025 huruf G, juga menegaskan bahwa dalam era reformasi upaya perwujudan sistem hukum nasional terus dilanjutkan mencakup beberapa hal: Pertama, pembangunan substansi hukum, baik hukum tertulis maupun hukum tidak tertulis telah memunyai mekanisme untuk membentuk hukum nasional yang lebih baik sesuai dengan kebutuhan pembangunan dan aspirasi masyarakat... Kedua, pelibatan seluruh komponen masyarakat yang memunyai kesadaran hukum tinggi untuk mendukung pembentukan sistem hukum nasional yang dicitacitakan. ${ }^{14}$

Uraian tersebut menunjukkan, bahwa hukum tidak tertulis atau hukum adat memunyai kedudukan yang mapan secara konstitusional. Eksistensi hukum tidak tertulis ini dapat dirasionalisasikan ketika kepentingan politik pembentukan sistem hukum nasional atau pembaharuan hukum menuntut hukum tidak tertulis menjadi bagian dari sakralitasnya.

${ }^{14}$ Lihat Undang-Undang No. 17 Tahun 2007 tentang Rencana Pembangunan Jangka Panjang Tahun 2005-2025. 
Sosiolog hukum Satjipto Rahadjo menyebutkan, bahwa untuk mewujudkan kepastian hukum bukan hanya berarti undang-undang, sebab hukum lebih luas dari undang-undang; karena hukum itu meliputi hukum tertulis (undang-undang) dan hukum tidak tertulis seperti kebiasaan atau hukum adat. Negara Indonesia berdasarkan hukum, bukan negara berdasarkan undang-undang. ${ }^{15}$ Dalam ranah ini, hukum tidak tertulis justru bisa memberi lebih banyak terhadap keberlanjutan hidup masyarakat dan bangsa, termasuk memberikan kontribusi terhadap kepentingan pembaharuan hukum pidana.

J. Van Kan juga menyebutkan, bahwa hukum merupakan cermin (een weergave) dari masyarakat, sehingga selayaknya pembentukan hukum pidana Indonesia harus senantiasa mencerminkan nilai-nilai yang hidup di masyarakat Indonesia atau berlandaskan pada living law. ${ }^{16}$ Hal itu menunjukkan, bahwa hukum pidana selayaknya mencerminkan nilai-nilai yang hidup dalam masyarakat agar bisa diterapkan dan diterima serta memenuhi rasa keadilan masyarakat di mana hukum itu diberlakukan.

Pengakuan terhadap eksistensi nilai-nilai hukum dan rasa keadilan yang hidup itu diakui secara konstitusional sebagaimana telah penulis jelaskan sebelumnya. Dalam konstitusi kita (UUD NRI 1945) sudah jelas, bahwa negara memunyai kewajiban untuk mengakui dan sekaligus merespon perkembangan hukum adat. Negara tidak boleh membiarkan masyarakat adat menjadi masyarakat kelas dua atau masyarakat yang terpinggirkan. Hakhaknya sebagai bagian dari wajah Negara Kesatuan Republik Indonesia wajib mendapat pengakuan.

Adanya ketentuan konstitusi tersebut berarti bahwa negara wajib mengakui sekaligus merespon perkembangan hukum adat dengan tetap mengakui keberadaan masyarakat adat itu sendiri. Secara nasional, terdapat diskursus terhadap sistem hukum nasional yang secara tidak langsung mengakui serta menganut sistem hukum barat dan di sisi lain harus konsisten mengakui keberadaaan hukum adat. Dalam hal ini, penting untuk dilacak antara keduanya apakah berada dalam dimensi saling berkompetisi, melengkapi atau berada pada rezim sendiri-sendiri.

Apabila kita lacak dari dasar konstitusi Undang-Undang Dasar 1945, maka sesungguhnya dengan adanya hasil amandemen ke-4 telah dinyatakan secara eksplisit dalam Pasal 18B bahwa (1) Negara mengakui dan menghormati satuan-satuan pemerintah daerah yang bersifat khusus atau bersifat istimewa yang diatur dengan undang-undang. (2) Negara mengakui dan menghormati kesatuan-kesatuan masyarakat hukum adat berserta hak-

${ }^{15}$ Satjipto Rahardjo, Hukum Dalam Jagat Ketertiban, (Jakarta: Penerbit UKI Press, 2006), hlm. 135.

${ }^{16}$ Bambang Satriya, Problematika Pembaharuan Hukum Pidana Nasional, (Jakarta: Komisi Hukum Nasional Rebublik Indonesia, 2013), hlm. 273. 
hak tradisionalnya sepanjang masih hidup dan sesuai dengan perkembangan masyarakat dan prinsip Negara Kesatuan Republik Indonesia, yang diatur dalam undang-undang.

Dalam materi muatan Pasal 18B ayat (2) UUD 1945 tersebut, secara normatif dapat ditarik menjadi 4 (empat) unsur yang harus diperhatikan sebagai prasyarat eksistensi dan validitas masyarakat hukum adat di Indonesia yang dengan sendirinya akan teridentifikasi nilai-nilai yang hidup dan diakui sebagai hukum adat dalam masyarakat adat tersebut. Syarat pertama adalah unsur "sepanjang masih hidup". Dalam kalangan masyarakat adat tertentu, ada yang tidak mampu mempertahankan kehidupannya, sebagai akibat dari keterpurukan hidup, yang mencari kehidupan di tempattempat atau lingkungan daerah lain, sehingga ia sebagai individu dengan yang lain tidak memunyai pertalian darah. Akibatnya, kekuatan hukum adat yang menjadi dasar kehidupannya selama ini, lama kelamaan menjadi pudar, akhirnya hilang sama sekali.

Unsur kedua dalam rumusan Pasal tersebut adalah "sesuai dengan perkembangan masyarakat". Syarat ini tentu dapat diartikan bahwa hal-hal yang menjadi ketentuan-ketentuan tradisionalnya, tidak boleh bertentangan dengan kemajuan masyarakat dewasa ini yang tidak dapat menghindarkan dirinya dari kehidupan global. Unsur ketiga yang wajib dipenuhi dalam pemenuhan entitas masyarakat hukum adat secara penuh adalah "prinsip Negara Kesatuan Republik Indonesia". Syarat ini sudah selayaknya dan harus dimiliki setiap masyarakat hukum adat. Hukum yang diberlakukan dalam masyarakat tersebut, benar-benar murni suatu perwujudan dari ketentuan kebiasaan-kebiasaan tradisional yang telah secara turun-temurun dilaksanakan. Negara Kesatuan Republik Indonesia harus menjadi suatu tujuan utama yang hendak dicapai dalam rangka mendorong eksistensi hukum adat serta masyarakat adat.

Unsur terakhir yang menjadi dasar bagi masyarakat hukum adat dalam ketentuan pasal tersebut adalah "yang diatur oleh undang-undang". Dalam perspektif penulis terminologi ini merupakan salah satu kuncian yang sangat berbahaya dalam eksistensi masyarakat hukum adat. Hal ini dikarenakan bahwa sejatinya masyarakat hukum adat bertitik tolak dari hukum yang tidak tertulis melainkan dinamis yang hidup berkembang di masyarakat. Keempat unsur dalam perumusan pasal ini setidaknya menjadi dasar secara konstitusional untuk megakui keberadaan masyarakat adat dan sekalian hukum adatnya. Terpenuhinya keempat syarat tersebut, secara otomatis sistem hukum masyarakat adat tersebut tetap berada pada tertib hukum yang ditegakkan atas sanksi-sanksi hukum adat dalam hubungan-hubungan yang bersifat kontraktual psikologis.

Seiring perkembangan zaman, perkembangan bangsa dan Negara Kesatuan Republik Indonesia, kini kian banyak memerlukan berbagai 
kekuatan sanksi hukum publik, yang ditunjang oleh wibawa nasional, tak hanya berkarakter administratif, tetapi juga berkarakter pidana. Proses kriminalisasi pun bermunculan sebagai konsekuensinya, diperlukan pembaharuan hukum, khususnya hukum pidana. Berbicara tentang pembaharuan hukum atau perkembangan hukum di Indonesia, dapat diketahui dari sisi kekuasaan kolonialisme belanda di Pulau Jawa yang berlangsung lebih dari satu abad (1840-1950), berlanjut dengan berbagai modifikasi serta adaptasinya untuk kepentingan pembangunan suatu negara nasional yang modern, pada era 1840-1990 disebut sebagai perkembangan dari hukum kolonial ke hukum nasional ${ }^{17}$ hingga Indonesia merdeka dan berlanjut hingga sekarang.

Dalam rentang perjalanan sejarah yang panjang, kondisi hukum bangsa Indonesia telah dipengaruhi secara nyata oleh peradaban Eropa, yang membawa pemahaman dan sistem hukum termasuk hukum pidana yang hingga kini berlangsung di seluruh nusantara. Hukum pidana barat masih berlaku, dan sangat terasa bersifat kolonial, kolot, egosentris, bahkan sangat postivistik sehingga menimbulkan pergolakan dalam tataran pengembangan keilmuan, bahkan masalah keadilan dalam praktek kehidupan. Hukum pidana yang berlaku di Indonesia, ialah hukum pidana yang telah dikodifikasi, yakni sebagian besar aturan-aturannya telah disusun dalam suatu Kitab Undang-Undang Hukum Pidana (KUHP). Karenanya, upaya pembaharuan hukum pidana terus dilakukan.

Sejak tahun 1966, penggarapan naskah rancangan undang-undang hukum pidana baru telah dilaksanakan, dengan melakukan berbagai politik hukum kriminal sebagai suatu upaya yang rasional dari masyarakat untuk menanggulangi kejahatan. Proses kriminalisasi berlangsung sejak dibentuknya UU No. 1 Tahun 1946 tentang KUHP dengan perubahan sifat hukum pidana yang disesuaikan dengan kemerdekaan Indonesia, dan hal demikian berlangsung hingga sekarang. ${ }^{18}$

Hukum pidana adat Indonesia yang tersebar di berbagai kesatuan hukum adat, adalah cermin dari peradaban asli bangsa Indonesia yang pernah memperlakukan hukum adatnya. Alam pikirannya bersifat komunalisme dan religio-magis. Kedudukan manusia adalah sentral. Manusia merupakan bagian dari alam kosmos, selalu seimbang, terjaga dan bilamana dan gangguan, maka segera dipulihkan. Hukum adat tersebut tidak mengenal hukum yang statis, tiap-tiap peraturannya timbul, berkembang dan selanjutnya lenyap, karenanya perubahan hukum, perubahan zaman diikuti oleh perubahan peraturan. Perubahan-perubahan itu dipengaruhi oleh rasa

\footnotetext{
${ }^{17}$ Soetandyo Wignyosoebroto, , Dari Hukum Kolonial ke Hukum Nasional, Dinamika SosialPolitik Dalam Perkembangan Hukum di Indonesia, (Jakarta: Raja Grafindo Press, 1995), hlm. 2-3.

${ }^{18}$ Sudarto, Hukum dan Hukum Pidana, (Bandung: Alumni, 1986), hlm. 29-32.
} 
keadilan lahir batin masyarakatnya. Oleh karena itu, diharapkan setiap pembaharuan hukum di Indonesia, tidak terkecuali pembaharuan hukum pidana (materil maupun formil) sebagai bentuk pengakuan terhadap keadilan lahir batin yang dikehendaki masyarakat Indonesia.

Salah satu konsep pokok bentuk pengakuan hukum yang berkembang atau hidup di masyarakat adalah dengan diadopsinya sistem sanksi dalam hukum adat (pidana adat) dalam sistem hukum nasional sebagai bentuk pembaharuan hukum pidana nasional. Pengakuan dan perlindungan atas penerapan sanksi hukum adat menjadi suatu yang penting dalam kehidupan masyarakat adat, sebab dengan sanksi adat, maka dapat terkonstruksi atau tercipta keseimbangan dan harmonisasi sosial, kepentingan antara golongan manusia dan perorangan, antara persekutuan (kelompok) dan masyarakat luas yang merupakan dasar dari alam pikiran tradisional bangsa Indonesia.

Kongres-kongres PBB mengenai "The Prevention of Crime and The Treatment of Offenders" juga menggariskan, bahwa sistem hukum pidana yang ada selama ini di beberapa negara, yang sering berasal (diimpor) dari hukum asing semasa zaman kolonial pada umumnya telah usang dan tidak adil (absolete and unjust) serta sudah ketinggalan zaman dan tidak sesuai dengan kenyataan (outmodel and unreal) karena tidak berakar pada nilainilai budaya dan bahkan ada 'diskrepansi' dengan aspirasi masyarakat serta 'tidak responsif' terhadap kebutuhan sosial masa kini. ${ }^{19}$

Keinginan kuat untuk meng-Indonesiakan hukum adat atau hukum yang berkembang di tengah masyarakat, secara tidak langsung dapat dipahami melalui laporan Kongres PBB ke VI atau Sixth UN Congress on "The Preventions of Crime and The Treatment of Offenders" (New York, Departement of Economic and Social Affairs, 1981), bahwa "Acapkali, ketiadaan konsistensi antara undang-undang dengan kenyataan merupakan faktor kriminogen; semakin jauh undang-undang bergeser dari perasaan dan nilai-nilai yang hidup di dalam masyarakat, semakin besar ketidakpercayaan akan keefektifan sistem hukum itu". ${ }^{20}$

Membahasakan realitas perkembangan hukum adat (pidana adat) ke dalam RUU KUHP atau ranah pembaharuan hukum pidana nasional memang tidak mudah, karena hukum adat (pidana adat) bersifat pluralisme. Di masing-masing daerah terdapat keragaman sanksi-sanksi pidana adat yang bisa dijadikan sebagai bagian dari kearifan muatan lokal guna mewarnai pembaharuan hukum pidana nasional.

Memasukkan beberapa sanksi pidana yang berkembang di masyarakat adat merupakan wujud pembaharuan hukum dengan model mengIndonesiakan hukum pidana adat dengan harapan, bahwa masyarakat adat di

\footnotetext{
${ }^{19}$ Op.Cit., Barda Nawawi Arief, Beberapa Aspek...., hlm. 128-129.

${ }^{20} \mathrm{Ibid}$.
} 
seluruh Indonesia memunyai payung untuk berperilaku dan mempertanggungjawabkan berbagai bentuk perbuatan yang berkategori pelanggaran atau kejahatan adat.

\section{Penutup}

Memasukkan hukum adat yang jelas-jelas bersifat pluralistik di Indonesia memang bukan hal mudah. Akan tetapi pentingnya pengakuan terhadap nilai-nilai yang hidup di masyarakat sebagai hukum adat (pidana adat) dalam sistem hukum nasional sebagaimana agenda reformasi hukum secara nasional merupakan kebutuhan dan tuntutan untuk pemenuhan keadilan sosial sesuai cita-cita nasional bangsa Indonesia.

Sudah saatnya negara atau badan legislatif bekerja keras untuk menformulasikan hukum adat menjadi bagian dari hukum pidana nasional. Politik nasionalisasi pembaharuan hukum berbasis kearifan lokal menjadi suatu keharusan seiring dengan tuntutan masyarakat terhadap penegakan keadilan yang benar-benar berbasis kemaslahatan rakyat.

\section{Daftar Pustaka}

Arief, Barda Nawawi, 2010, Bunga Rampai Kebijakan Hukum Pidana (Perkembangan Penyusunan Konsep KUHP Baru), Bandung: Citra Aditya Bakti. 2005, Beberapa Aspek Kebijakan dan Pengembangan Hukum Pidana (Edisi Revisi), Bandung: Citra Aditya Bakti. Bandung: Citra Aditya Bakti.

Bakhri, Syaiful, 2013, Hukum Pidana, Perkembangan dan Pertumbuhannya, Jakarta: Total Media \& P3IH Fakultas Hukum Universitas Muhammadiyah.

Muladi, Arief, Barda Nawawi, 1998, Teori-Teori dan Kebijakan Pidana, Bandung: Penerbit Alumni.

Rahardjo, Satjipto, 2006, Hukum Dalam Jagat Ketertiban, Jakarta: Penerbit UKI Press.

Sakidjo, Aruan; Poernomo, Bambang, 1990, Hukum Pidana: Dasar Aturan Umum Hukum Pidana Kodifikasi, Jakarta: Ghalia Indonesia.

Satriya, Bambang, 2013, Problematika Pembaharuan Hukum Pidana Nasional, Jakarta: Komisi Hukum Nasional Rebublik Indonesia.

Sudarto, 1986, Hukum dan Hukum Pidana, Bandung: Alumni.

Supusesa, Reimon, Eksistensi Hukum Delik Adat Dalam Perspektif

Pambaharuan Hukum Pidana di Maluku Tengah, Mimbar Hukum, Volume 24, Nomor 1, Februari 2012 
Teguh, Prasetyo, Halim, Barakatullah Abdul, 2005, Politik Hukum Pidana Kajian Kebijakan Kriminalisasi dan Dekriminalisasi, Yogyakarta: Pustaka Pelajar.

Wignyosoebroto, Soetandyo, 1995, Dari Hukum Kolonial ke Hukum Nasional, Dinamika Sosial-Politik Dalam Perkembangan Hukum di Indonesia, Jakarta: Raja Grafindo Press.

Undang-Undang No. 17 Tahun 2007 tentang Rencana Pembangunan Jangka Panjang Tahun 2005-2025. 